\title{
PARA ALÉM DA GANGRENA
}

Ruy Fausto

Que o leitor me desculpe, mas começarei citando a mim mesmo. Acho que é importante que cada um de nós faça um balanço daquilo com que contava e daquilo com que não contava. Principalmente para aqueles que, como eu, votaram até aqui no PT.

\section{1}

Quando ocorreu o caso Waldomiro Diniz, assessor de José Dirceu, publiquei na Folha de S. Paulo um artigo que se chamava "A Gangrena" (a Redação modificou o título que passou a ser "O PT, Dirceu e o risco de gangrena", Folha de $S$. Paulo, 28 de março de 2004). Nele - cito o original enviado, o texto que saiu é uma versão reduzida, mas fiel - eu dizia entre outras coisas: "Trata-se simplesmente da desatenção de um ministro, que se enganou ao escolher um assessor? (...) Infelizmente as circunstâncias nos fazem pensar que a gravidade é maior. (...) esse não é o primeiro caso suspeito que envolve gente do PT, houve pelo menos mais uma história grave, os fatos obscuros de Santo André, que culminaram (...) com o assassinato do prefeito Celso Daniel (...)". E continuava: "Nessas condições, ou o PT procede a uma 
verdadeira análise de consciência, e mais do que isto, a uma limpeza geral das suas práticas, ou a gangrena, é preciso dizer, será inevitável. (...) O PT chega ao limite do que pode ou antes do que não pode [fazer] um partido de esquerda. Dirceu tem de ser substituído (...) se Lula tiver a coragem de demitir Dirceu, ele ganhará o apoio de tudo o que existe de melhor na sociedade civil e na política brasileiras (...) (...) Se o governo Lula persistir nesse caminho, ele perde sua alma, e mais cedo ou mais tarde, os melhores partirão". O texto terminava dizendo: “(...) acho que só um movimento nacional de resistência por parte dos eleitores de Lula (...) poderia salvar o governo e o PT. Por que não um abaixo-assinado nacional pedindo (...) a demissão de Dirceu?". Cito mais um texto, que precede de quase dois anos ao anterior. Trata-se de uma entrevista à Mais!, de junho de 2002, com o país em plena campanha para as eleições presidenciais (cito de novo a versão maior): "Lula justifica alianças com o PL e até com Quércia. (...) Na realidade o problema das alianças é por um lado ético e por outro lado político. Alianças são válidas e possíveis, mas um partido de esquerda democrática que se preze não faz alianças: 1) com gente claramente à direita (...); 2) com gente notoriamente corrupta. A primeira exigência é política, a segunda é ética, mas uma ética que se exige da política, que deve estar incluída na política de um partido de esquerda democrática. (...) Se não for corrigido, o caminho que o PT está seguindo, conduzirá à morte desse partido. Votarei em Lula, porque acho que os erros ainda são reversíveis (...) Mas o destino da esquerda brasileira não se identifica com o destino do PT, e ainda menos com o destino de Lula". E se o PT insistir nesse caminho?, perguntava o repórter. "Votaria em branco (...) até que se formasse un novo partido, reunindo as forças socialistas e democráticas não contaminadas pelo oportunismo e pela corrupção. Essa não seria a primeira vez que um partido de esquerda teria apodrecido." 
Com isso, não pretendo dizer que (só) acertei nas previsões. Nos 25 anos do PT, publiquei um artigo no site comemorativo que, apesar de todas as críticas e previsões, era, sem dúvida, excessivamente otimista. Na realidade, até os casos Celso Daniel e, depois, Waldomiro Diniz, preocupavam-me (preocupavam-nos?) essencialmente a corrupção vinda de fora, através das alianças. Dentro do PT, supúnhamos, poderia ocorrer algum caso de corrupção, mas isto em pequena escala, em todo caso em escala bem menor do que nos outros partidos. E se quando os dois problemas apareceram, enxerguei a gangrena como alguns outros observadores o fizeram, não supus entretanto que ela tivesse essa extensão. O porque da relativa cegueira de muitos de nós (aliás a cegueira foi mais ou menos geral) deve aparecer no que se segue.

\section{2}

Hoje, onde estamos? A primeira coisa a discutir é por que aconteceu o que aconteceu. Seria preciso fazer um balanço da história do PT (incluindo o governo petista) e, dentro dela, um balanço da história do que se pode chamar - denominação clássica - de degenerescência do partido. Na história do PT, em geral, acho que há duas coisas a assinalar como ponto de partida. Em primeiro lugar, a diversidade interna do partido, e a outra a virada política que se opera já antes das eleições. O PT se desenvolve como uma frente de tendências de esquerda, frente que é estranha ao movimento comunista e também à social-democracia. Os elementos de que se origina essa frente - mas eles vão se redestribuir em diferentes tendências dentro do partido - são: certa intelectualidade de esquerda relativamente independente, setores de esquerda da igreja, ex-militantes (ou militantes) de extrema-esquerda, e gente ligada ao movimento sindical. Essa diversidade, ou antes a diversidade das tendências que se constituirão a partir desse material - cristalizam-se sobretudo uma extrema-esquerda revolucionária, e uma 
tendência não revolucionária mas com linguajar também radical - poderia representar uma vantagem (assim como a independência em relação aos PPCC e também à socialdemocracia). Lendo os documentos antigos publicados no vigésimo quinto aniversário do partido, fica-se impressionado com a quantidade de argumentos críticos que lá aparecem, apesar de que, evidentemente, nem tudo é muito claro. Porém essa diversidade oferecia perigos. Quando o PT passa a ser governo, o problema se coloca de maneira aguda. Mas antes disso, seria necessário assinalar que com a Carta ao Povo Brasileiro, deu-se uma virada radical na perspectiva política do partido. A Carta ao Povo Brasileiro poderia ser entendida como um programa provisório, e nesse sentido poderia ter sido aceito pelo menos por algumas das tendências (devo dizer que como recusa da perspectiva revolucionária - perspectiva comum, na linguagem, a todas as tendências - e como programa econômico de transição, ela era certamente positiva). Mas pouco a pouco se descobre que a virada se instala como programa definitivo. E aí se instaura uma ruptura não só com o pior, mas também com o melhor do que se dizia antes, e com as posições do conjunto do partido. Entretanto, as diferentes tendências continuaram existindo, ocupando algum lugar no governo, e conseguindo mesmo concretizar, pontualmente, alguma coisa da sua perspectiva ou programa; embora parte da extrema-esquerda acabe sendo expulsa, num procedimento bastante brutal. Assim, teve-se um governo com uma política econômica ortodoxa, que se foi revelando definitiva, mas política que coexistia com iniciativas de outro tipo ao encontro da perspectiva de outras alas, inclusive as de uma esquerda ainda bastante radical. Com um pouco de maldade, poder-se-ia dizer que em vez da síntese do melhor das diferentes tendências, teve-se uma somatória do pior: ortodoxia econômica (isso foi a novidade), laxismo (leniência) em relação a certas mobilizações abusivas de pseudo-movi- 
mentos de massa, desenvolvimentismo mas autoritário por parte da direção de certo banco estatal, e por cima de tudo, burocratismo e corrupção. Mas houve políticas positivas implementadas, principalmente nos setores da educação e da energia, em matéria de bolsas etc., mas políticas muito prejudicadas pelo engano que foi o conjunto.

\section{3}

Mas vamos por partes. O problema principal é analisar as relações entre a história propriamente política do partido, incluindo a grande virada, e a questão da corrupção, ou do burocratismo e da corrupção, se o leitor preferir. Esquematicamente, o problema é o das relações entre posições políticas, na sua diversidade, e corrupção. Há muita confusão a esse respeito. Ora se reduz o problema da corrupção a uma questão política, em sentido estrito, o que é um erro; ora se vê apenas o problema ético, perdendo de vista o lado político. Eu partiria da idéia de que se a corrupção não pode ser pensada isoladamente, ela não é entretanto simples derivado, e deve ser estudada em si mesma. Começo assim me perguntando pela sua gênese. Há uma gênese interna do fenômeno da degenerescência petista (burocratização e corrupção), mas há também elementos externos. Creio que, internamente (em duplo sentido, privilegiando o que aconteceu dentro do PT, e analisando "compreensivamente", isto é "em interioridade", o processo) a gênese é dupla. A corrupção, no PT - quero dizer o seu "sentido" e a sua autojustificação - veio tanto pela esquerda como pela direita. Com isso não estou dizendo que toda a direita petista se corrompeu, e menos ainda acusando de corrupção toda a esquerda do PT. A degringolada ética se situa, de certo modo, num outro plano. Há direitistas éticos e nãoéticos. Há esquerdistas éticos e não-éticos. Ou, mais exatamente, há corruptos com uma figura esquerdizante, e há os que têm, antes, uma tendência "direitista". O que quero 
dizer é que havia um caminho "pela direita" e um caminho "pela esquerda" em direção à corrupção. Ao tratar desses dois caminhos, será preciso considerar por um lado uma certa extrema-esquerda, já que o "caminho pela esquerda" começa ali; e no outro pólo, referir-se não só ao "direitismo corrupto petista", mas - embora limitadamente, para não sair muito, por ora, da análise interna - também à direita em geral, de cujo espírito aquele se impregnou. Embora de modo diferente, o "transcendental" (isto é, a ordem do dever-ser ético) é estranho à extrema-esquerda como a boa parte da direita. $\mathrm{O}$ caminho da corrupção pela esquerda - são principalmente ex-guerrilheiros que a representam, mas nem todos os ex-guerrilheiros seguiram esse caminho - é bem conhecido, e ele deve ter aparecido muito cedo no PT, bem antes da Carta ao Povo Brasileiro. A esquerda revolucionária tem um objetivo, a revolução. Ela poderá criticar a corrupção da política capitalista, mas para ela, a corrupção é epifenômeno. A corrupção é adjetiva; substantivo é o capitalismo. E se a extrema-esquerda considera que a corrupção da direita é produto da lama geral do capitalismo, quando a corrupção está a serviço da esquerda, sua atitude é ambígua. Ela admite, na prática pelo menos, que a corrupção pode servir. $\mathrm{O}$ governo bolchevique comprava pasquins na imprensa ocidental para defender o poder soviético. As relações do governo castrista com as máfias internacionais da droga são ambíguas - voltarei ao assunto mais adiante -, para não falar da guerrilha colombiana. Os PPCC não hesitaram em fazer alianças com os populistas mais corruptos. Esses exemplos mostram que a extrema esquerda, em todas as suas versões, nunca teve grande respeito por exigências de ordem moral. Mas ao mesmo tempo, é um fato que os revolucionários bem intencionados (ou mais ou menos bem intencionados, deixo claro que "objetivamente" não considero o leninismo "bem intencionado") sempre hesitaram no uso desses meios. No caso do PT, não é a extrema-esquerda 
mais coerente (ou relativamente coerente) que vai seguir o caminho da corrupção, mas uma ex-extrema-esquerda marcada pelo stalinismo, e que de algum modo continuou fiel a ele. Evidentemente, a corrupção ocupou o lugar que era o da violência. Hoje mesmo, em plena crise, escuta-se freqüentemente a seguinte conversa: se pelo menos eles tivessem roubado para fazer tais ou quais mudanças radicais! $\mathrm{O}$ que mostra como, para muita gente, a democracia é simples meio a serviço de certos fins, estes sim essenciais. Que o uso da corrupção como meio para as mudanças oblitere necessariamente esse fim, disto certo tipo de extrema-esquerda não têm consciência. $\mathrm{O}$ que poderia também ser explicado discutindo a natureza dos fins. Se esses fins forem a sociedade comunista, em princípio - na realidade, mesmo nesse caso só em princípio - tudo seria possível. De alguma forma, todos os meios são válidos para uma política de "tábula rasa". Mas se os objetivos hoje não são esses - e um mínimo de reflexão sobre o destino das revoluções no século XX deveria pôr de lado definitivamente o projeto utópico comunista - a questão dos meios se coloca de outro modo. Não há projeto socialista que possa ser efetivado através da corrupção, porque a liquidação - ou a redução radical - da corrupção é parte essencial dele.

A corrupção "pela direita", cujo suporte vem sobretudo de militantes ou ex-militantes sindicais, já se manifesta também desde antes da virada política. Mas no momento em que se dá a virada, abrem-se-lhe novas possibilidades. Certos militantes pensavam mais ou menos assim: abandonamos as ilusões quase-revolucionárias, agora somos políticos realistas como todos os outros. Dizia-se em 2002 que quem se mostrasse reticente em relação a uma eventual aliança com Quércia revelaria não ter abandonado ainda todo sectarismo e todo fanatismo revolucionário! Em suma, se os neostalinistas eram anti-éticos já nas suas origens e por razões "revolucionárias", os que abandonaram propriamente todo 
projeto e linguajar revolucionário ou quase-revolucionário foram descobrindo - talvez já o conhecessem, também através de uma prática sindical duvidosa - um mundo em que a ética servia como verniz ideológico para uma prática em essência muito pouco ética. E aderiram a ele.

Mas o "rio de lama" que nasceu da confluência daquelas duas correntes formadoras (neo-stalinistas e simplesmente "realistas"), penetrou num pântano já existente e se alimentou dele. Todos sabem que a corrupção não começa com o PT, embora isso não possa ser de forma nenhuma uma razão para justificar o partido, ou mesmo atenuar a sua culpa. A situação é complicada. Porque por um lado, é absurdo tentar inocentar o PT, ou antes os corruptos dentro do PT, a partir do argumento de que a corrupção já existia antes deles. Por outro lado, essa pré-existência é um elemento essencial para entender e julgar o conjunto do processo. $\mathrm{O}$ fato de que o PT se apresentava com um programa "ético" agrava certamente o seu caso, mas ao mesmo tempo não é uma razão que permita absolver outros partidos. Dar uma pena maior ao ex-bom menino - e é preciso discutir aliás até onde e em que sentido ele foi mesmo um "bom menino" do que aos meninos que nunca foram bons, sob pretexto de que, precisamente, os últimos nunca foram bons..., tem algo de injusto. Mas num certo plano, a precisar, o argumento tem alguma verdade. Por exemplo, é claro que o argumento vale, se se provar que o "ex-bom menino" foi mesmo mais longe do que tudo aquilo que fizeram os outros.

Porém, mais precisamente, como o PT chegou até onde chegou? $\mathrm{O}$ processo que conduziu à situação atual vai pouco a pouco aparecendo nas margens dos jornais, no meio de uma enxurrada de fatos meio repetitivos e de ordenação complexa. O PT não tinha dinheiro para as campanhas, e não havia, ou quase não havia empresários, que se dispusessem a ajudá-lo. Ressalve-se que havia e há alguns empresários que contribuem para o PT, por razões de ideologia pes- 
soal. O partido tenta, aliás sem sucesso, legalizar a possibilidade de auxílios sindicais. Até que, em certo momento - de quem partiu a iniciativa? - empresários (não simpatizantes do partido) se dispõem a "ajudar" o PT. Por que razão, não é dificil imaginar. Empresários não gostam de meter todas as fichas na mesma cartela, e, devia haver indícios (o próprio irrealismo dos projetos) de que o discurso revolucionário do PT não teria um grande futuro. Por uma razão ou por outra, certos empresários se dispuseram, assim, a ajudar o PT. Isso foi o que ocorreu pelo lado da oferta. Pelo lado da procura, já vimos: o PT crescia e precisava de dinheiro para as campanhas. Na realidade, a coisa é mais complicada ou, sob outros aspectos, se simplifica, porque o partido chega um dia ao poder (primeiro, ao poder municipal, depois a poderes estaduais e à presidência). E nesse momento, os empresários que contribuem não recebem apenas vagas promessas de apoios futuros, mas contratos municipais de valor variável. É nesse contexto que se deve entender o funcionamento das duas "correntes de motivação" que indiquei anteriormente. A turma que vai abandonando os projetos quase-revolucionários saúda o realismo do "toma lá dá cá" que mostra um partido como os outros, partido que vai crescendo e que deve oferecer também certas vantagens individuais. (A corrupção em favor do bolso próprio, existente sem dúvida sabe-se lá desde quando dentro do PT, deve ter sido, apesar de tudo, um componente segundo, pelo menos se comparado com o papel que teve na história de Collor.) Quanto aos revolucionários-sem-revolução (os neo-stalinistas), o quadro lhes era também muito alentador. Já que a violência revolucionária sofrera grandes derrotas no país (o que pouco a pouco dava origem à idéia de que no Brasil - mas não fora - ela não representaria o melhor caminho), era justo que se pusesse em seu lugar algo tão "radical" mas menos arriscado, e mais condizente com os "costumes gerais" da política brasileira e da política em geral. Essas 
duas tendências, embora tenham se "espalhado" muito dentro do PT (no sentido patológico do "espalhar") representaram de certo modo só uma "camada" dentro dele. Paralelamente, havia uma camada sã ou relativamente sã - a maioria dos intelectuais estava aí, com o que não quero dizer que não tenha havido intelectuais comprometidos com o pior - camada que, um pouco, a exemplo do que ocorria com a parte "infectada", ocupava todo um leque de posições: a esquerda, o centro e provavelmente também a direita do partido. Das duas tendências do "rio de lama", a neo-stalinista é bem representada por Dirceu, se é que ele não é o seu único representante (teríamos então uma "classe de um só elemento” ...). Um Delúbio e vários outros chefes caídos da cúpula petista, representam bem a outra tendência.

\section{4}

Um passado de quem arriscou a vida lutando contra

212 a ditadura enriquece sem dúvida um currículo, mas não é salvo-conduto ético nem político para ninguém. Porém, até onde sei, nem mesmo esse título Dirceu pode ostentar legitimamente. Era um líder estudantil que veio a ser preso. Foi libertado pela iniciativa de outros, e foi deportado para Cuba. Por que ninguém conta a história dos brasileiros em Cuba? Segundo me foi contado por um deles, muito cedo alguns exilados se deram conta de que o poder castrista era um intolerável regime policial. Mas evidentemente não apregoavam isso em público; só comentavam entre eles. E o detalhe que nos interessa: quando falavam sobre o assunto, o volume da voz se reduzia, se por acaso Dirceu se aproximasse... Desconfiavam de que ele fosse ligado diretamente a tal ou qual serviço do governo castrista. (Reproduzo uma conversa: não posso garantir que o relato dessa manifestação de desconforto seja verdadeiro, mas não me parece implausível.) E aqui seria importante se deter um momento a propósito do que representa o regime castrista como escola políti- 
ca. Afinal vários elementos de cúpula do governo Lula e do PT são, ainda hoje, grandes admiradores do ditador cubano, e alguns deles mantêm contato direto e freqüente com ele. Já que o castrismo é assim um modelo político cultuado por muita gente desse meio, entre os quais está o personagem que representa o pivô da crise atual, desenvolver esse ponto não é inútil para fazer um diagnóstico completo sobre o significado da crise. Em outro lugar já tive a oportunidade de escrever a respeito do poder castrista, mas acrescento alguns dados. Há dois pontos sobre os quais conviria insistir. Uma é a atitude do governo castrista diante da corrupção (corrupção de Estado no caso), e a outra é a sua atitude diante da violência e do crime. Parece bem estabelecido que a condenação e execução de Ochoa e La Guardia, acusados entre outras coisas de tráfico de drogas, ocultava certos contatos com os traficantes que eram efetuados pelo próprio governo castrista. Foi provavelmente para evitar o escândalo que eles foram executados. (Isso interessa para desmisticar a ilusão de que o castrismo, ou a adesão ao castrismo, estaria no extremo oposto ao da indulgência para com a corrupção). Porém, há mais grave do que isto: o emprego que os irmãos Castro fizeram e fazem não só da violência em geral, mas do crime político. Os ingênuos costumam justificar tudo em nome da famosa "violência revolucionária", expressão muito ambígua que pode ocultar o pior. Na realidade, os irmãos Castro e seus associados liquidaram literalmente todos aqueles que se opuseram à guinada comunista da revolução democrática, guinada que foi de fato uma contra-revolução neo-stalinista asfixiando a revolução. Conhece-se o caso de Huber Matos, o quarto homem cubano do movimento, que passou vinte anos na prisão e só não foi liquidado, por que a ditadura temia consequências políticas no plano internacional. Menos conhecido, e ainda mais grave é o episódio da morte de Camilo Cienfuegos, o terceiro homem cubano da revolução. É quase certo que Camilo Cienfuegos foi 
liquidado pelos irmãos Castro (ver Castro, l'infidèle, de Serge Raffy, os livros de Carlos Franqui, a autobiografia de Matos, etc, etc). Há provas testemunhais de que o pequeno avião de Cienfuegos foi abatido por um caça cubano obedecendo a instruções superiores, ainda que as provas testemunhais tenham se reduzido, porque várias das pessoas envolvidas no caso morreram em condições misteriosas. Ao que tudo indica, tratou-se de um crime político. Por que isso nos interessa no momento atual? Interessa, insisto, porque mostra bem o caráter mais profundo do castrismo e o castrismo foi a escolinha em que estudaram alguns dos nossos ex-revolucionários. Coisa importante, porque, se uma parte evoluiu e abandonou definitivamente suas ilusões com o poder dos tiranos "de esquerda", outra parte, mesmo quando afirma que o castrismo "não é a via para o Brasil", continua vendo nele um modelo de "esquerda pura", de política de esquerda bem intencionada, antípoda de tudo o que aconteceu

214 aqui. Na realidade, há parentescos ocultos. Nesse sentido, o apelo, em face da crise, à memória de certos ícones do pensamento radical que muito admiravam o castrismo - "que diria de tudo isto o professor X, se ainda estivesse vivo?” - , por honestos que tenham sido esses ícones é um grave malentendido. Como o são também as lágrimas de crocodilo de certos frades, íntimos das tiranias caribenhas e usufruidores das suas mordomias, que se pronunciam como se tivessem lições a dar. Sem dúvida entre as práticas do poder petista (pelo menos até onde se sabe) e os lados mais sinistros da (contra-) revolução castrista (ainda) há uma distância considerável; porém não deixa de existir certa convergência na maneira à vontade com que uns e outros se utilizam de certos meios, e essa convergência precisa ser assinalada, se quisermos ter um quadro suficientemente amplo e completo do processo em curso. A deriva mafiosa de parte da esquerda brasileira tem, de fato, várias genealogias. Mas o castrismo ocupa certamente um lugar privilegiado em uma delas. 
Quanto à outra tendência, não há muito a acrescentar. Um amigo sociólogo lembrava, apoiando-se provavelmente no livro clássico de Michels sobre a burocratização, o papel que desempenha em tudo isso o fator "arrivismo". A atração a que são vulneráveis ex-proletários - ou ex-membros da camada assalariada pobre em geral - pelas grandes massas de dinheiro postas à sua disposição, e pelas grandes possibilidades que ela oferecia em termos de consumo.

Talvez se pudesse distinguir também de um modo intrínseco ou formal as duas tendências, e a partir daí, diferenciar as "tradições" que lhes facilitaram a inserção na política brasileira. Se as duas visam tanto o poder como a corrupção (mas visa-se o poder para obter vantagens ilícitas, ou visam-se vantagens ilícitas para ganhar poder?) poder-se-ia dizer, talvez, que a primeira, a dos "revolucionários stalinistas de novo tipo" está mais centrada no poder (seu projeto é antes o de corromper para obter poder) e a segunda, a dos burocratas sindicais, centra-se, antes, na corrupção (ganhar poder par obter vantagens ilícitas). Se isso é verdade, as duas se inserem na história nacional também de forma um pouco diferente: uma na "prática tradicional" de corrupção e abuso dos fundos do Estado, que sempre se manifestou na sociedade brasileira; e a outra, como foi assinalado por certos observadores, na tradição autoritária que sempre teve impacto sobre a vida política do país. Mas as duas tendências confluíram, adotando (e desenvolvendo) as práticas que caracterizaram a sociedade civil e a política brasileiras tais como existiram até aqui.

\section{6}

Esquematicamente, há dois pretensos herdeiros da crise, isto é duas tendências principais, que pretendem "faturar" em cima dela. Elas se situam, de novo, à esquerda e à direita. Mas se também na genealogia da degenerescência 
reconheciam-se motivos e filiações de esquerda e de direita, aqui se trata, em grande parte pelo menos, de outra coisa: de um lado, da extrema-esquerda petista ou ex-petista "autêntica", que não se envolveu (ou se envolveu pouco?) na corrupção, e pelo outro lado, essencialmente, da direita (e do centro) em sentido geral, exteriores ao PT. Ambos tentam obter as vantagens que o caso parece oferecer. Vejamos quais são os argumentos de uns e outros, e qual a validade desses argumentos. A extrema-esquerda trata de mostrar que tudo vem da politica neoliberal do governo, e tenta provar que o essencial não está na corrupção mas naquela política. Por mais que se possa e deva criticar a política neoliberal, o argumento é enganoso. Não há uma relação necessária entre o neoliberalismo e a corrupção. E o essencial: para quem acredita na democracia, a corrupção é um problema em si mesmo, o que não é o caso para a extrema-esquerda, como já vimos. Inversamente, a direita (talvez também a direita do PT, mas sobretudo a direita em geral) culpa a extrema-esquerda pela deriva mafiosa, esquecendo: 1) que a filiação "revolucionismo" / corrupção não é a única genealogia da crise; e, 2) que uma parte importante (talvez a maioria) da esquerda do PT não foi envolvida pelo processo. Assim, é preciso pôr ordem nos argumentos de uns e de outros. Em relação à extrema-esquerda, além das razões já examinadas, seria preciso lembrar que "entidades" do tipo MST (e outras do mesmo estilo; o MST é em grande parte um pseudo-movimento social, algo mais próximo de um partido semi-totalitário, que abusa de um nome) aproveitaram-se bem das verbas do governo. A forma pela qual o MST recebe dinheiro do governo é regular e legal? Lembremo-nos de que o MST não tem expressão legal, e recebe dinheiro através de ONGs, nominalmente a serviço da reforma agrária ou de cooperativas. Se esse repasse de verbas se revelar ilegal como reagirá certa esquerda? Justificará as ilegalidades em nome de pretensos interesses revolucioná- 
rios? Lembremos que há uma CPI (ou CPMI) que examina a questão do financiamento do MST, infelizmente, pelo que parece, controlada pela direita. Mas a melhor esquerda tem todo interesse em que as investigações vão até o fim. Em geral, pergunto-me como funciona o movimento financeiro do que constitui sem dúvida alguma um lobby castro-chavista que existe no país e para além dele, lobby que tem seus representantes bem inseridos em jornais, revistas, agências, instituições estatais e paraestatais, ONGs etc etc. Atualmente ocorre uma divisão no interior da extrema-esquerda, separando os defensores do governo, e os que o atacam e pedem o impeachment. Os primeiros não querem perder as suas "vantagens", os últimos têm mais coragem e não têm rabo preso, mas isso não quer dizer que sua tendência pró-impeachment seja uma boa alternativa, no momento atual.

Quanto à direita e ao centro, seria bom lembrar que embora o argumento de que houve "irregularidades" também sob o governo Cardoso não possa servir para inocentar o PT ou mesmo atenuar sua culpa, a direita e o centro brasileiros não têm muita autoridade para se apresentar como os campeões da honestidade. Curiosamente, um filósofo-ideólogo, muito próximo do poder cardosista, que se tornou conhecido por um discurso arqui-ambíguo sobre "o momento a-moral" da política, tenta dar lições a propósito do processo em curso. Seria necessário reler, hoje, o que ele escrevia sobre o caso Collor. Uma leitura cuidadosa dos seus textos da época, e também dos seus textos posteriores (permito-me remeter o leitor à introdução geral do meu Marx: Lógica e Política III, p. 34 a 39, para uma análise detalhada) mostra bem que, apesar das suas piruetas "teóricas", a interpretação aparentemente superficial, que vê no seu discurso um amoralismo no sentido de imoralismo ou antimoralismo, é na realidade a interpretação correta. De fato, ele escrevia coisas desse tipo em plena crise do governo Collor (os grifos são meus): "É preciso saber conviver com a infra- 
ção contra valores alheios (sic) para que tenhamos política." E mais precisamente: "Que o presidente da República venha a público, como chefe de Estado, clamar pela moralidade pública, ao mesmo tempo que trata de defender seus interesses particulares, tudo isso está nas regras do jogo.” “(...) e se cometer alguma falta, mais vale que mantenha as aparências do que venha se confessar em público”. “(...) a sociedade necessita tanto de seus fundamentos formados por interesses conflitantes quanto de um espelho em que os interesses são projetados, julgados e coibidos em nome da justiça (...)". "Daí a regra política de que todo político que for pilhado agindo em interesse próprio deve ser punido." Veja-se bem: a lição fundamental desses textos (que são de grande mediocridade teórica, disfarçada por uma retórica que só encanta certo jornalismo pró-tucano seletivamente crítico) é a de que o essencial é não ser descoberto. O essencial não é ser honesto. Se o autor não se pronuncia abertamente pela desonestidade, ele também não se manifesta em favor da honestidade, o que basta para configuar um imoralismo. As práticas de Collor evidentemente não lhe pareciam anormais desde que não se deixasse descobrir. Ora, esse filósofo-ideólogo se apresenta hoje, como se tivesse lições a dar. Na realidade, ele é parte da crise e contribuiu para ela. Junto com outros, ele contribuiu para dar certo tipo de legitimação, e banalizar, o faça o que quiser, mas não seja descoberto, que foi sempre o lema dominante. Nesse sentido, as acusações que ele faz contra o "moralismo" - essa clássica imputação fraudulenta também foi utilizada por outros, na crise atual, o que mostra a necessidade de desmistificá-la, para além da crítica desse autor - são completamente infundadas. O que ele chama de "moralismo" é na realidade, como acontece freqüentemente, a crítica ao amoralismo. E esta tem plena justificação. Quanto ao que é realmente moralismo, ele é certamente mistificador, mas isso não pode servir de argumento para justificar o amoralismo (diga o ideólogo o que quiser, amo- 
ralismo equivale aqui a imoralismo). Sem querer demonizálo, lembremos também que Cardoso só muito tardiamente se juntou aos que pediam o impeachment de Collor. Quanto ao governo Cardoso, quando saberemos em detalhe - ou nunca saberemos - o que se passou no processo das privatizações e no da reeleição? Isso tudo pertence apenas à "história", como ele sugere, ou interessa também ao presente? Ou ainda, levando em conta certas declarações recentes do ex-presidente : supondo que a separação seja possivel, a corrupção "estadual" ou "regional" interessa menos do que a corrupção "federal"? Para além dos tucanos, é triste ver o uso que fazem da crise os ACMs e os Sarneys. A direita-direita exulta. Bornhausen diz que se sente feliz em "se ver livre dessa gente (ou esta "raça"?) por trinta anos". Só os ingênuos pensarão que por "essa gente", ele visa apenas corruptos ou burocratas. $\mathrm{O}$ bando que roda em torno dele não é certamente de melhor qualidade ética. O jornal $O$ Estado de $S$. Paulo tem um herói: Palocci. Todos os outros, todos aqueles que criticam uma estabilidade, cujo preço é a eternização das desigualdades e os lucros fabulosos dos grandes bancos, entram na conta do bolchevismo. A ofensiva da direita mostra o mal que os espertalhões da direção petista fizeram à esquerda. Eles prestaram o melhor serviço que poderiam prestar à direita. Por isso mesmo, toda indulgência em relação a eles só desserve a esquerda.

\section{7}

Porém, sem atenuar as responsabilidades, é preciso analisar o significado mais geral desse processo. Creio que há duas reflexões teóricas a fazer sobre o conjunto dele. A primeira é a de que, no fundo, o que se tem aí é um aspecto de um problema muito importante: o das relações entre democracia e capitalismo. Capitalismo e democracia coexistem, mas há entre os dois uma tensão que aparece em diferentes níveis. Ela se manifesta no interior do processo 
de trabalho, ela aparece também no mercado de trabalho (principalmente na situação de desemprego crônico) etc. A corrupção do poder político é um outro aspecto, do mesmo problema, na realidade um aspecto sui-generis. Sui-generis porque, ao contrário do que ocorre em geral para as outras vertentes, aqui se trata de alguma coisa que se manifesta como uma transgressão das regras do sistema democráticocapitalista, mesmo aos olhos do sistema, embora se trate de uma transgressão que, de fato, seja mais ou menos a regra... Em suma é uma questão que, diferentemente das outras, é levantada pelo próprio sistema democrático-capitalista, pelo menos em certo nível. Como garantir o funcionamento da democracia diante do poder gigantesco das empresas à cata de vantagens, principalmente na área dos contratos do Estado? Há aí uma dificuldade, que não é só brasileira, e para a qual é preciso buscar uma solução. Nesse sentido, a crise brasileira, como as crises anteriores que sacudiram outros países, é de interesse universal e de importância teórica considerável. A acrescentar que, no caso brasileiro, os processos empregados foram muito longe, provavelmente mais longe do que o que se viu em geral até aqui. Não só, como ocorreu em outros países, perverteu-se o sistema de licitações, que virou um sistema de trocas comerciais entre decisões do Estado, pilotadas por um grupo, beneficiando algumas firmas, e contribuições dessas firmas à máquina política montada pelo mesmo grupo. Houve mais do que isso. A adesão a partidos e os votos no Congresso também se transformaram em mercadorias. Embora esses fatos não sejam inéditos nem aqui nem no exterior, o sistema é "admirável" pela sutileza e pela sistematicidade. $\mathrm{O}$ grupo no poder administra a entrada de deputados da oposição em partidos-satélites, espécie de filiais ou de franquias do partido-mãe, contra o pagamento de "luvas". Como se não bastasse, novos e velhos associados, nas filiais e também na matriz, ainda ganhavam para confirmar que o seu voto será favorável ao governo, por ocasião da 
votação de diferentes projetos. Montou-se assim uma estrutura econômica mafiosa de poder, um "capitalismo mafioso de Estado" que, pelo seu "engenho" e sistematicidade deve ter superado o que se havia feito anteriormente na matéria. Se as CPIs se dispuserem mesmo a condenar os culpados, deve haver provas testemunhais suficientes e, sem dúvida, um número considerável de provas documentais bastantes, para que se condenem os que devem ser condenados. Diante de tais fatos, o cinismo de certos acusados só é menos chocante do que a ingenuidade (ou o cinismo) de alguns que, das galerias, asseguram que os fatos não são tão graves, ou não foram suficientemente estabelecidos.

A segunda reflexão importante, mas que em parte já está contida no que foi dito no parágrafo anterior, diz respeito à própria esquerda, em particular às formas de degenerescência da esquerda. A crise revela novos aspectos do fenômeno conhecido da degenerescência dos partidos de esquerda. Tradicionalmente, conhecem-se duas formas de degenerescência, em grandes linhas, simetricamente opostas: de um lado o stalinismo (mas, a meu ver, também o leninismo que, apesar das suas boas intenções "subjetivas", é a ante-sala daquele), de outro o chamado "reformismo". Num caso, liquida-se a democracia (junto com o capitalismo) e se instaura um pseudo-regime de transição ao socialismo, na realidade um despotismo burocrático de tipo "igualitarista". No segundo caso, tem-se ou microrreformas ou uma pura e simples adaptação ao regime existente, capitalista-democrático. A rigor, o termo "reformismo" já não convém hoje. Porque o que se tem hoje é o fenômeno dos governos de esquerda que praticam as políticas de direita as mais ortodoxas. Não se trata de reforma, mas de conservação do sistema democrático-capitalista na sua variante mais conservadora no plano econômico e social. Conhecia-se também uma terceira forma de degenerescência (ou de "falsa-esquerda") que é o populismo. Penso no populismo do tipo Chaves, 
também o de Peron ou de Vargas. Aí também se asfixia a democracia (em geral não tão radicalmente), mas modificando apenas as regras do capitalismo, sem liquidá-lo. Experiências negativas como a do PT não se enquadram a rigor em nenhum dos três casos: não houve degenerescência no sentido da imposição de um poder "stalinista"; houve sem dúvida algo da "degenerescência reformista", aliás mais na figura daquela que não visa reformas mas abraça o statu quo mais conservador. Entretanto, não houve apenas isso. Também não se trata exatamente de "degenerescência populista", pelo menos no sentido de Chaves, Vargas ou Peron. Na realidade, o PT não atentou contra a democracia. $\mathrm{O}$ apelo de tipo direto à massa foi até aqui reduzido. E não ocorreram práticas de tipo plebiscitário. Claro que poderíamos falar de um populismo de outro tipo. Mas seria impreciso. Acho que se teve aí um quarto tipo de degenerescência, a acrescentar à "degenerescência stalinista", à reformista (ou simplesmente "adesista") e à "populista". Degenerescência que se poderia chamar de "mafiosa". Nesse caso, não se atinge a democracia nem na forma stalinista, nem na forma populista, mas também não se trata de simples adesão ao sistema democráticocapitalista. Há sem dúvida adesão, mas específica, digamos, adesão ao submundo do sistema democrático-capitalista, aos subterrâneos dele. Adesão ao negativo do sistema, mas não no sentido da introdução de uma forma superior a ele, e sim ao negativo como o universo da transgressão "criminosa" das regras do sistema. Essa forma de degenerescência é específica e tem de ser entendida e combatida enquanto tal. Mesmo e sobretudo se o seu objetivo não foi essencialmente o enriquecimento pessoal, mas o fortalecimento da máquina.

\section{8}

A quantas estamos e quais são as perspectivas? O problema geral, dizia, tem a ver com o da relação - mais precisamente, com o da tensão - entre democracia e capitalismo. 
Ora, se a reação de muitos, incluindo a extrema-esquerda, está centrada na crítica do neoliberalismo, ela toma também freqüentemente a forma de um ataque contra a democracia. Ou pelo menos contra a "democracia representativa", o que não melhora muito as coisas, apesar das aparências. Recentemente, um jurista do PT escreveu um texto propugnando uma espécie de democracia direta, onde se pode ler: "Na estrita verdade dos fatos (...) longe de ser um simples mal-entendido (...) a democracia entre nós foi e continua a ser mero disfarce ideológico, um roto véu que mal encobre a nudez da dominação oligárquica. Aceitamos todas as fórmulas políticas e dispomo-nos a experimentar quaisquer novidades, desde que se possa manter e fazer funcionar uma democracia sem povo" (Fábio Konder Comparato, Folha de S. Paulo, 5 de agosto de 2005). O texto é ambíguo mas o engano é visível. $\mathrm{O}$ autor quer opor a democracia direta à democracia representativa, e provavelmente a democracia tal como existe lá fora à democracia como existe entre nós. Mas o resultado é um ataque contra a democracia brasileira enquanto tal. Quaisquer que sejam os defeitos da nossa democracia - e eles são enormes - chamá-la de "mero disfarce ideológico" ou "roto véu (...) que encobre a nudez da dominação oligárquica", é abrir fogo contra as nossas instituições democráticas enquanto tais. O que temos no Brasil é uma democracia representativa e não outra coisa. E tê-la obtido de volta depois do interregno militar foi uma conquista da maior importância, apesar de tudo. Por outro lado, é uma ilusão pensar que a chamada "democracia direta" seja uma panacéia. Sem dúvida, pode-se multiplicar as instituições do tipo "orçamento participativo", etc. Mas, primeiro: elas não podem substituir a representação. E segundo: a partir de certo nível, elas são perigosas. Todo mundo sabe em que deu certo tipo de poder plebiscitário (as consultas diretas à população são hoje proscritas na Alemanha), o que não significa que os referendos não possam 
ter certo papel. Mas não mais do que isto. O engano grave desse texto é supor que a democracia representativa seja a responsável pela crise, o que aliás se inscreve numa desastrosa tradição anti-democrática, da qual a esquerda ainda não se libertou. Certas práticas que se desenvolvem facilmente no interior do capitalismo ameaçam a democracia ? Alguns propõem uma solução curiosa: acabar com a democracia... É como se matar o doente fosse o melhor meio de liquidar a doença. Muita gente, de um universo político não muito diferente, é sensível à idéia de que a crise indica como único caminho a via revolucionária. Plínio de Arruda Sampaio afirma numa entrevista recente: "É hora do socialismo no Brasil. Porque, quando o Lula não consegue fazer reformas dentro do capitalismo por causa desse estado de sítio em que se encontra (sic), isso demonstra só uma coisa: Lula é a última tentativa de uma transformação pela via de reforma no capitalismo" (Folha de S. Paulo, 22 de agosto de 224 2005). A última frase contém uma aposta obscura ou arbitrária. Em que sentido a tentativa de Lula é a última? Ou, em outros termos, o que significa para o autor "reforma": recusa da insurreição armada? De minha parte, diria que ou a esquerda adota finalmente o caminho democrático, e mais, a democracia representativa - porque a democracia "direta” ou é tolerável em forma homeopática ou é remédio perigoso - ou não haverá saída para a crise.

Se a exigência democrática - e democrática "representativa" - é essencial, ela não é, entretanto, por si só, suficiente. Precisamos de um programa econômico, programa não liberal, mas também não aventureiro ou "arcaico". A esse respeito, não posso ir muito longe: os economistas criticos têm muito a dizer. Mas nesse programa - falei disso no texto, citado, sobre o caso Dirceu (2004) - a mudança das regras de cobrança do imposto de renda é essencial. O sistema atual é inteiramente injusto; pesa demais sobre os pequenos e insuficientemente sobre os que podem pagar. 
Mas há muito mais coisas a decidir ou definir: reduzir os juros, alterar o câmbio, estudar a atitude em relação aos capitais especulativos etc. E a meu ver, é preciso levar a sério e explorar a fundo as possibilidades das experiências cooperativas. Por ora, quase ninguém, fora do círculo dos seus promotores diretos no plano econômico ou político, leva a sério esse tipo de iniciativa.

Porém, em terceiro lugar, para além disso, ou aquém, impõe-se um programa específico de luta contra a corrupção. Nesse capítulo, há por um lado todo uma agenda de reformas eleitorais para reduzir o custo das campanhas e eventualmente dar maior peso aos partidos. Parte dele já está em discussão, mas veremos em que vai dar. Não entrarei em detalhes sobre as melhores soluções, mas acho que um sistema misto de voto individual-distrital seria o melhor. O sistema de listas partidárias tem vantagens e desvantagens que é preciso discutir. Há também a questão das regras e limites para a propaganda eleitoral etc., etc. Porém, além dessas medidas, seria preciso mexer na questão das licitações. Caso não se chegue a um controle efetivo das licitações, os problemas permanecerão. É preciso que os juristas estudem modalidades de controle, talvez através de comissões nomeadas pelo judiciário, não sei. Se fosse possível que, nas licitações, houvesse sorteio entre propostas julgadas mais ou menos equivalentes, teríamos uma situação interessante. De qualquer modo, ou se encontra uma solução para o caso das licitações, ou nada será resolvido. A acrescentar, num plano que não é o da política, mas é sempre o da corrupção, que se impõe um programa efetivo de luta contra a sonegação fiscal. Vamos ver se a direita virtuosa mostra algum entusiasmo em relação a ele. De qualquer modo, é impossível que o país continue tolerando o volume de sonegação que existe aqui. Para além disso tudo, parece necessária uma reforma política mais geral, reforçando partidos e dando maior estabilidade a governos, reforma que garanta 
um sistema menos vulnerável à corrupção. Assim, existem saídas, embora elas não sejam panacéias.

\section{9}

No plano partidário, refiro-me ao destino da esquerda, é difícil dizer no momento em que escrevo (final de agosto de 2005) se o PT irá sobreviver. E qual será o seu destino. Também não sabemos se o governo Lula sobreviverá. A melhor perspectiva seria a de que o PT se salvasse, com a expulsão dos corruptos e uma reorganização do centro e da esquerda menos fanatizada, na base de um novo programa econômico e político. Um programa definido, sem retórica inútil, sem concessões aos poderes dominantes, e absolutamente intransigente em relação à corrupção. Nesse caso, o ideal seria buscar um candidato que não fosse o Lula, para as próximas eleições presidenciais, e aceitar a idéia de uma possível derrota. Uma cura de oposição não seria má para a esquerda. Mas se não houver uma reorganização do partido, sucedendo necessariamente a um processo de expulsões, o PT apodrecerá; e o melhor do PT abandonará o partido. Infelizmente, no momento em que escrevo, essa é a perspectiva que me parece a mais provável. Para onde iriam então os dissidentes? Há bastante gente séria e honesta no PT, embora reine muita confusão. Talvez eles se dispersem em uma série de legendas sem muita expressão. Outra hipótese negativa: eles tomarão o caminho da extrema-esquerda. A extrema-esquerda acertou e acerta ao denunciar o processo de corrupção do partido, mas suas perspectivas políticas são irrealizáveis ou nefastas. A terceira possibilidade, no interior da hipótese da vitória do pior dentro do PT e da ruptura dos melhores, seria a formação de um novo partido, de esquerda democrática. Não creio que isso anuncie grandes vitórias ou grandes mudanças, mas no fundo seria o melhor, ou o mal menor, caso o PT apodreça irremediavelmente. Tentar-se-ia organizar um partido com um programa de esquerda democrática. 
Ele teria uma função crítica, poderia talvez obter algumas vitórias eleitorais num plano regional. E reuniria o que há de melhor na esquerda brasileira. Quando ao resto, veríamos. $\mathrm{O}$ essencial seria tentar formular um programa político democrático de esquerda, suficientemente claro e bem definido. E evidentemente construir um partido que levasse a sério o problema da corrupção e da burocratização.

Há um outro lado que precisa ser posto em evidência. O dos movimentos sociais. Os pseudo-movimentos sociais do tipo MST, a demagogia das lideranças esquerdistas no movimento estudantil, e a corrupção no movimento sindical, fizeram com que se deteriorasse a imagem dos movimentos sociais. A própria noção de "movimento social" está completamente deturpada. Este é o presente, que deram à direita, demagogos e aventureiros de toda sorte. Com relação ao MST, se há quem tenha ilusões, diria que a atitude dele em relação aos camponeses é paternalista e autoritária, para não dizer mais. Se se quiser ter uma idéia do que isso e outras coisas mais significam, considere-se o estilo, para-totalitário, da escola de quadros que, com dinheiro público, ele fundou no interior de São Paulo. Mais do que nunca, será fácil, para a direita, atacar os "movimentos sociais”, com o que, ela golpeia não só as direções demagógicas ou aventureiras, mas também os próprios movimentos. É importante dizer que a esquerda e o país precisam do movimento camponês, do movimento estudantil, e do movimento sindical. O que não significa que precisem de certos líderes, e mesmo de certas entidades que falam em nome desses movimentos. Nos países em que a social-democracia foi mais bem sucedida (Escandinávia), os sindicatos são extremamente fortes, e eles gerem honestamente, até onde sei, instituições de previdência e também fundos de pensão. Não fosse o poder dos sindicatos, e certas democracias sociais, que estão entre as mais avançadas do mundo, seriam absolutamente impossíveis. Sem querer transpor experiências, é evidente que o Brasil tem necessidade de um movimento sindical combativo, não dema- 
gógico, e honesto. $\mathrm{O}$ mesmo deve ser dito do movimento camponês e do movimento estudantil. Não tenho condições para discutir onde estão os melhores germes de desenvolvimento no interior das dezenas de organizações que pretendem representar os camponeses, nas várias organizações de trabalhadores, e no movimento estudantil. Digo apenas, tomando posição ao mesmo tempo contra a direita e contra uma certa esquerda corrupta ou aventureira, que é preciso distinguir, de um lado, as direções (e em alguns casos as entidades), e, de outro, o próprio movimento. Se de fato, atualmente, a separação não é tão simples, - de direito e a longo prazo ela não só é possível, mas é condição de sobrevivência do movimento.

\section{0}

A vitória petista apareceu como uma grande esperança para a esquerda mundial. Essa esperança se desfez. Com um pouco de otimismo, é possível supor que as lições da crise

228 sejam fecundas. Mas antes disso, haverá um longo processo de reflexão e de reorganização.

Estou convencido de que só aqueles que acreditam na democracia, poderão dar contribuições efetivas, para entender e superar a situação atual. Mas só os que propugnam uma "mutação dentro da democracia" (e não o simples reformismo ou o adesismo, e também não as aventuras insurreicionais) serão capazes de indicar os remédios a longo prazo. É um trabalho longo, difícil, que supõe, entre outras coisas, a coragem de enfrentar o sistema dos preconceitos dominantes, preconceitos que, sob formas diferentes, ocupam o universo político, da extrema-esquerda à extrema-direita.*

\section{Ruy Fausto}

é professor emérito da Faculdade de Filosofia, Letras e Ciência s Humanas da USP

\footnotetext{
* Artigo concluído em 29 de agosto de 2005.
} 


\section{PARTE II}

\section{PARA ALÉM DA GANGRENA}

RUY FAUSTO

$\mathrm{O}$ artigo critica algumas das interpretações correntes sobre a crise do governo Lula e do PT. Ao relacionar as causas da corrupção recentemente encontrada a certo pensamento (e prática) com fundas raízes na Esquerda, o texto também tenta avaliar conseqüências da crise.

Palavras-chave: Governo Lula; Partido dos Trabalhadores (PT); Esquerda; Corrupção.

\section{BEYONG GANGRENE}

The article criticizes some current interpretations of the Lula administration and the Workers Party's crisis. In relating the recently uncovered corruption to a certain thought (and practice) with deep roots in the Left, the text also tries to evaluate the consequences of the crisis.

Keywords: Lula Administration; The Workers Party (PT); The Left; Corruption. 